\title{
The Interface between Neighbors at a Time of State Transition The Thick Border of the Bolsheviks (1917-1924)
}

\author{
Sabine Dullin
}

In the forests and swamps of Belorussia after the Russian-Polish War, a song was going the rounds: "What do I hear and what do I see? / There's Trotsky perched on a roof / Bellowing to the plebs: / 'Freedom, it's behind you!"' In this song, Leon (Lev) Trotsky, who at the time was touring the civil-war battlefronts by train as war commissar and head of the Red Army, is portrayed as the herald of a freedom on which the people have turned their backs. The new border that was being etched out at Riga is presented here as a frontier between conflicting values and principles. On which side did freedom lie? Those who turned the wrong way would pay a high price.

Between 1917 and 1924, territorial sovereignty in the borderlands of the former empires of eastern Europe was in the throes of a major crisis, brought about by war and revolution. ${ }^{2}$ All the old affiliations had been thrown into question. Traditional regalian authority seemed to have imploded with the collapse of the existing states, and national self-determination was the pervasive discourse, an abstract slogan open to highly diverse interpretations and practices. Violence and

This article was translated from the French by Rodney Coward and edited by Angela Krieger, Nicolas Barreyre, and Chloe Morgan.

1. There is an allusion to this song in the tale of the smuggler Sergiusz Piasecki, Lover of the Great Bear, trans. John Mann (London: Routledge, 1938).

2. This crisis of sovereignty, revealed in migrations and choices concerning citizenship, has notably been studied in relation to the German context by Annemarie H. Sammartino, The Impossible Border: Germany and the East, 1914-1922 (Ithaca: Cornell University Press, 2010). 
coercion were widely employed by mutually antagonistic social and political forces, but each locus of power claiming sovereignty also needed to justify and convince people of its legitimacy. At the heart of this reconfiguration of boundaries lay the experiment of the Bolshevik revolution, with its subversive effect upon traditional hierarchies, its ideological refusal of territorial annexations and former state limits, and its class-based, internationalist definition of sovereignty.

For all that, did this irruption of political radicalism into the territorial organization of eastern Europe lead to the establishment of a new type of border and an original way of managing the interface between two hostile and divergent social and political systems? Had the Bolsheviks not come to power in Russia, had the collapse of the existing empires led to the establishment of state and national boundaries that did not imply a radical ideological otherness, had the independent states of Russia and Ukraine shared the same political principles as Poland, the Baltic states, and Finland, would administrative practices at the border, and hence the everyday lives of the populations, have been different? The purpose of this article is to examine whether the restructuring of the borderlands carried out by the Bolshevik state resulted in a specific mode of administration of the populations and territories in question. ${ }^{3}$ Only the new European border of the early Soviet republics will be studied here, since all parties involved considered it a battlefront in the struggle for adhesion to or rejection of Communism; it is therefore different from the other Soviet borders, where the principal issues at stake were predominantly postcolonial. ${ }^{4}$ The perspective adopted in this study is principally that of the authorities in charge of the new border and touches only marginally on the lived experiences of the populations residing there, especially since the sources used at the central, republic, and local levels limit any attempt to study this aspect of the question.

The historiography of the USSR was long dominated by the idea of the specificity and exceptional nature of the construction of the Soviet polity. However, once it became possible to access primary sources, historians started deemphasizing this rupture in order to stress the continuity between the old regime and the revolution in terms of both actors and state practices. ${ }^{5}$ More recently, there has been increasing scholarly interest in the circulation of social, cultural, and political practices (including forms of repression) between the Soviets and their contemporaries. ${ }^{6}$ After two decades of such reevaluations in the writing of the history of

3. The discussion presented here forms part of a wider study of Soviet borders, undertaken with the support of the Institut universitaire de France. See Sabine Dullin, La frontière épaisse: Aux origines des politiques soviétiques, 1920-1940 (Paris: Éditions de l'EHEss, 2014).

4. Sophie Coeuré and Sabine Dullin, eds., Frontières du communisme. Mythologies et réalités de la division de l'Europe de la révolution d'Octobre au mur de Berlin (Paris: La Découverte, 2007).

5. Peter Holquist, Making War, Forging Revolution: Russia's Continuum of Crisis, 19141921 (Cambridge: Harvard University Press, 2002); Juliette Cadiot, Le laboratoire impérial. Russie-URSS, 1860-1940 (Paris: CNRS Éditions, 2007). 
the USSR, it is now time to return to the question of the political break that the revolution represented with the past, but with a new approach. In their study of the constantly modified, complex formation of the Soviet federation, Jeremy Smith and Terry Martin have shed light on the Bolsheviks' true capacity for innovation and a systematic approach, beyond their various legacies and external influences. ${ }^{7}$ This article moves in the same direction and poses the following question: What arrangements did the Bolsheviks invent at the border? The answer offered here makes no claim to be exhaustive, but focuses on administrative innovation in the fields of diplomacy and policing. The monographs on state and party structures during those crucial formative years that would enable us to get a complete view of Bolshevik border policies remain to be written. ${ }^{8}$ To date, the Foreign Trade Commissariat and customs authorities have not been studied since the archives were opened to researchers. ${ }^{9}$ Some notions that have long formed the backbone of analyses of Bolshevik power, such as democratic centralism or the monopoly on foreign trade, still await proper deconstruction, and lie somewhere between political myth and actual organizing principles of people and things. ${ }^{10}$ As we shall see, the Communists' relationship to questions of state and territory in Russia was a complex one. While the antistatism of The State and Revolution, written and published by Vladimir Illich Lenin in 1917, does not provide a lasting key to understanding the Bolshevik mode of government, mistrust of the state was part of the new regime's political culture. Policemen who had served the old regime were among the preferred targets of the Red Terror, and the public administrations undergoing reconstruction were placed under the control of the Workers' and Peasants' Inspectorate in 1920. In the early stages, sovereignty was exercised

Histories in the Age of Extremes," in "Fascination and Enmity: Russia and Germany as Entangled Histories, 1914-1945," special issue, Kritika: Explorations in Russian and Eurasian History 10, no. 3 (2009): 415-22; and Sabine Dullin, "How to Wage Warfare without Going to War? Stalin's 1939 War in the Light of Other Contemporary Aggressions," trans. Susan Pickford, Cahiers du monde russe 52, nos. 2/3 (2011): 221-43.

7. Terry D. Martin, The Affirmative Action Empire: Nations and Nationalism in the Soviet Union, 1923-1939 (Ithaca: Cornell University Press, 2001); Jeremy Smith, The Bolsheviks and the National Question, 1917-1923 (London: Macmillan Press/School of Slavonic and East European Studies, 1999).

8. In certain areas of Soviet studies, nothing new has been added since the work of early scholars such as Richard Pipes, Leonard Schapiro, and Edward Hallett Carr.

9. The only dissertation on foreign trade dates back to 1969 and approaches the question from a purely quantitative angle, without providing much information on the institution or the actors involved: see Michael R. Dohan, "Soviet Foreign Trade in the NEP Economy and Soviet Industrialization Strategy 1913-1938," (PhD diss., MIT, 1969). While it is still true that access to sources concerning foreign trade remains difficult in Moscow, this could be compensated by consulting the archives of the individual former republics and regions.

10. The following short but enlightening book should, however, be mentioned: Andrea M. Chandler, Institutions of Isolation: Border Controls in the Soviet Union and its Successor States, 1917-1993 (Montreal: McGill-Queen's University Press, 1998). Chandler stresses the importance of the monopoly on foreign trade as a factor in the early closing of the territory's borders. 
through the soviets and the party, to counterbalance a state that was already considered excessively cumbersome and over a territory that was not yet the be-all and end-all of the new authorities' political action.

My reflection has also been enriched by broader historiographical work on the construction of modern states. I am particularly interested in the approach that strives to decompartmentalize political history by decentering it, and to consider state practices from a transborder perspective. ${ }^{11}$ Indeed, the study of forms of interaction and transfer at the border, of processes of institutional mimetism, and of radical incompatibility between states offers ways of rethinking the construction of territorial sovereignty as a situation marked by contact and interface, as a transaction rather than an exclusively internal process centered around a single nation-state. ${ }^{12}$ As Peter Sahlins has pointed out, a border depends upon a process that is both internal and external, upon learning to separate where there is contiguity. ${ }^{13}$ A further objective is to understand how the exercise of sovereignty can create strangeness and distance out of what appear to be the border's particular characteristics-that is, familiarity and even indiscretion. ${ }^{14}$ Because it analyzes interstate relations between neighbors in border zones from the perspective of everyday life, and considers diplomatic negotiations from the concrete and technical viewpoint of micromanagement, this crossborder study of the state aims to provide new perspectives for a history of international relations from the bottom up.

What, then, is the appropriate scale for such a study? Neither the ultimately vague, exogenous category of borderlands nor the boundary line as negotiated, delimited, and then demarcated on the ground seem capable of accounting for the border as it was constructed through the practices of public authorities and administrators. If we want to be able to pinpoint its concrete effects on populations and territories, its salient characteristic is what might be called its "thickness." In the Soviet archives on which this study is based, the terminology most frequently used at the different spatial echelons of the political and administrative hierarchy is noticeably that of the "border zone," which, depending on the file, can either refer to an organizational principle or signify a place of action.

11. These studies have not always been the work of historians: George Gavrilis, The Dynamics of Interstate Boundaries (Cambridge: Cambridge University Press, 2008); Eric Tagliacozzo, Secret Trades, Porous Borders: Smuggling and States along a Southeast Asian Frontier, 1865-1915 (New Haven: Yale University Press, 2009); Mathijs Pelkmans, Defending the Border: Identity, Religion, and Modernity in the Republic of Georgia (Ithaca: Cornell University Press, 2006).

12. Michael Geyer analyzes different acts of historiographical deconstruction of the nation-state in "Historical Fictions of Autonomy and the Europeanization of National History," Central European History 22, nos. 3/4 (1989): 316-42.

13. Peter Sahlins, Boundaries: The Making of France and Spain in the Pyrenees (Berkeley: University of California Press, 1989).

14. The notion of indiscretion is sometimes used in research on the right of intervention. In such cases, indiscretion is defined as the "examination of an internal matter by an external authority." See Mario Bettati, Le droit d'ingérence. Mutation de l'ordre international (Paris: Odile Jacob, 1996), 16. 
The notion of the border zone has a history that is independent from the way Soviet politicians and administrators used it in the context studied here, and is intimately linked to the political geography of Friedrich Ratzel, who saw it as a transitional fringe of contact, confrontation, and interpenetration. ${ }^{15}$ Of course, the Bolsheviks had not read Ratzel and were ideologically far removed from both the international system of power relations and the Pan-Germanist thinking in which the term "border zone" evolved. Nevertheless, in the context of the Bolsheviks' territorial adventure, the notions of interface, showcase, and front take on a particular significance. Suffice it to mention the border arches, decked out in red drapes and bearing revolutionary slogans, which were set up at entry points after the formation of the USSR and were part of a border landscape that, while asserting the sanctuarization of the proletariat's homeland, refused to establish any status quo. ${ }^{16}$ During the same period, European legal experts seeking to comprehend the day-to-day exercise of sovereignty used the notion of the border zone in a very different sense to designate an area of "conventional neighbor relations," "a locus of juridical relations, creating rights and obligations." 17 This alternative definition proves rather enlightening when it comes to understanding what could be called the narrowing of the Bolsheviks' horizon and their adaptation to international norms. At the end of the civil war, the border zone assumed a functional, territorialized form comprising international zones, buffer zones, and free-trade or trade-facilitation zones, together with so-called "small-border" zones for the inhabitants who lived along it.

The term "border zone" thus provides a means of understanding political history in tension, and of showing how ideological demarcation went to the heart of the issues arising in the aftermath of the war, even as neighboring states had to jointly manage security and public order. It invites us to consider the processes of "co-construction" of territorial sovereignty by hostile countries, without necessarily examining each side of the boundary symmetrically. ${ }^{18}$ Indeed, the perspective adopted here seeks to show how Russian, Ukrainian, and Belorussian authorities adapted to this forced inter-state bilateralism, to gain an understanding of its limits, and to document some of the ways in which Soviet authorities diverted bilateral practices to their sole advantage.

The first part of this study provides an overview of Bolshevik theory and practice in matters of sovereignty, territoriality, and the establishment of borders. In the second part, I look at the border itself, an area where-as elsewhere in Europe-various ways of asserting sovereignty were tested within the framework of a bilaterally constructed border zone of a type hitherto little studied. The final section focuses on the question of whether Soviet authorities in the border area

15. Friedrich Ratzel, Politische Geographie oder die Geographie der Staaten, des Verkehres und der Krieges (Munich and Berlin: Oldenburg, 1903), chap. 17.

16. One such example is the Negoreloe triumphal arch: see Rossiiskii Gosudarstvennyi Arkhiv Foto-kino dokumentov, O-35052.

17. Paul Geouffre de La Pradelle, La frontière (Paris: Éd. internationales, 1928), 307.

18. Alan K. Henrikson, "Facing Across Borders: The Diplomacy of Bon Voisinage," International Political Science Review 21, no. 2 (2000): 121-47. 
were able to work within the rules of transborder relations and negotiations, given that their obsession with political control of the interface increasingly drove them toward unilateralism and led them to keep their neighbors at arm's length.

\section{Layers of Borders: A Revolutionary, Post-Imperial Construction}

With the collapse of the Russian Empire, the establishment of new borders was the order of the day. From 1903, the Russian Social Democratic Workers' Party had included the right to self-determination in article 9 of its party platform. After October 1917, two decrees sought to implement this: the Decree on Nationalities enshrined in law the right of each of the empire's non-Russian peoples to choose its sovereignty, and the Decree on Peace denounced all forms of annexation by force, defined as the incorporation of a nation that had not had the opportunity to vote freely on the forms of its national existence. For the protagonists involved, the establishment of the territorial limits of sovereignty, whether internal or external, had to obey identical principles. Since then, historiographical compartmentalization has to a certain extent severed the link that once existed between the internal reorganization of the new multinational state and the establishment of borders with neighboring countries. My aim here is to contribute to reestablishing this connection between what was played out on the internal border, on the one hand, and the unfolding of events on the external border, on the other. For the former, I have drawn heavily on the existing literature on the subject, particularly Jeremy Smith's book on the Bolsheviks and the national question. For the latter, I have mainly used political, diplomatic, and juridical sources.

\section{Between Class and Nation: The Resources of Horizontality and Fragmentation}

Throughout these years of revolution and civil war, the militant controversy over the nature of self-determination that had begun during the prewar years continued. Should the opinion of the working classes alone be taken into account, or should a plebiscite of the whole nation be envisaged? Some were hostile to the slightest concession to nationalist sentiment, while others-led by Lenin-saw the question as a psychological issue essential to the various populations' adhesion to the revolutionary cause. During the armistice and subsequent peace negotiations concluded at Brest-Litovsk in March 1918, the Bolshevik delegation, which was hardly in a position to impose conditions given the rout of the Russian army, demanded that the Germans withdraw their troops from the occupied territories so that plebiscites could be organized there. ${ }^{19}$ While the Bolsheviks used the plebiscite as a tool 
for propaganda in the early post-conflict period, there was nothing specifically revolutionary about it. ${ }^{20}$ However, the demand that all foreigners present in the country (mostly refugees and prisoners of war) be given the right to vote was more of an innovation. In 1918, the first constitutions of the Soviet republics integrated this conception linking citizenship to social, and not national, affiliation. Article 20 of the Constitution of the Russian Soviet Federative Socialist Republic (RSFSR), dated July 1918, speaks of a world citizenship (mirovoe grashdantsvo) extended to Communists of all countries. ${ }^{21} \mathrm{~A}$ compromise resolving the contradiction between nation and class was reached during the 1919 Eighth Party Congress, which had a lasting influence on Communist practices of annexation along their borders. This effectively involved a theoretical distinction between two types of national "plebiscite": the entire population would vote in territories where social differentiation and the workers' movement remained embryonic, while in areas where the class struggle was already a reality only proletarians would have a voice. In any case, satisfying the demands of non-Russians and hence the establishment of national limits, while considered politically necessary, did not result in a definitive separation. At most, they were envisaged as internal borders in an expanding revolutionary space, within which sovereignty would ultimately be returned to those who had previously been exploited. Political control of the territory during the Russian revolution was ensured through workers', soldiers', and peasants' councils formed in the towns and countryside. The recipients of many of Lenin's telegrams in the year 1918 were collectively known as Sovdepi-that is, various committees emanating from the soviets and charged with executive missions.

The revolution was followed by a devaluation of the notion of the border. To think out the international relations of the new Russia, Evgeni Korovin, an eminent jurist who had joined the Bolshevik cause, attempted to theorize a legal framework for the transitional period and a class-based concept of statal sovereignty. "The government of workers and peasants has never pretended to be a national power in the bourgeois sense of a 'sacred unity," he wrote. He insisted on the existence of a clear-cut border internationally and horizontally separating the dominant classes from the working classes, and described the new government as the "defender of the interests of the proletariat, both Russian and international," drawing on a series of examples taken from decrees, diplomatic notes, and treaty provisions dating back to the early years of the revolution. ${ }^{22}$ During those years, diplomatic action and the legal formalization of the interaction between the new Soviet republics and the outside world were in the hands of the most internationalist of the Bolsheviks. ${ }^{23}$ Adolf Joffe and Lev Karakhan, who had participated in the

20. Sarah Wambaugh, Plebiscites Since the World War: With a Collection of Official Documents, 2 vols. (Washington: Carnegie Endowment for International Peace, 1933).

21. Evgeni A. Korovin, Mezhdunarodnoe pravo perekhodnogo vremeni (Moscow: Gosizdat, 1923), 31.

22. Ibid., 28-29.

23. On the revolutionary radicalism of diplomatic personnel in the early 1920 s, see Valeri

A. Shishkin, Stanovlenie oneshnei politiki poslerevoliutsionnoi Rossii (1917-1930 gody) i kapitalisticheskii mir (Saint Petersburg: D. Bulanin, 2002). 
Brest-Litovsk negotiations alongside Trotsky, were actively involved in relations with Poland in 1920-1921 before pursuing careers in China. Khristian Rakovsky played a fundamental role in the diplomacy of early Soviet Ukraine, and it was Fiodor Raskol'nikov who implemented the anti-British policy of friendship with Afghanistan. Their superior, Georgy Chicherin, a former Menshevik, appears to have adopted radically different positions in his dealings with East and West. An ultrarevolutionary in the East, reproaching Joffe in 1923 for abandoning Mongolia to the White Russians, in his dealings with the West he adopted a policy in which continuity with the old regime was more perceptible. On both military and ideological levels, discussions_-and the decisions made-echoed the representation of a pioneer front, portraying the revolution as spreading from one Soviet republic to the next. The space of the revolutionary advance was not continuous: the core areas of worker and peasant sovereignty (soviets, party committees, and self-proclaimed republics) needed to be joined together. When, in the context of the German military defeat, the revolution seemed close to victory in Kiel and Berlin, Lenin had a stream of telegrams sent out to mobilize the Russian border guards on the Ukrainian border, the battalions of Lithuanian and Polish revolutionaries, and the Communists among the German soldiers occupying these territories-all in an effort to close the geographical gap in revolutionary forces. ${ }^{24}$ On November 18 , 1918, Trotsky, then commissar for military affairs, designated the borderlands of the new Soviet Russia as crucial for the expansion of the revolution. ${ }^{25}$ In early 1919, he and the Bolshevik commanders of the Ukrainian national units disagreed over their objectives. Trotsky and the Russian high command considered that the aim of the military operations in Ukraine should be to reach out toward the Hungarian revolutionaries, whereas the principal concern of the Ukrainian Communists was the defense of their territory.

In the Bolshevik leaders' spatial representations, there were thus two superimposed maps of territorial sovereignty. In the first, which was on the scale of the former Russian Empire, sovereignty was considered firmly established at the center but needed to be extended to the counterrevolutionary periphery. ${ }^{26}$ This was doubtless the map Joseph Stalin had in mind when, in his role as people's commissar for nationalities, he promoted the idea of territorial autonomy for the border regions lagging behind the center as early as April 1918. The second, on the scale of eastern Europe, showed the centers of revolutionary ferment, which were to be expanded toward each other if and when conditions were favorable. The borderlands of the first map became intermediary spaces on the second, sometimes corridors and sometimes barriers. In any event, the Soviet revolutionary territory, sobranie sochinenii, 5th ed., vol. 37 (Moscow: Politizdat, 1970).

25. Leon Trotsky, Kak vooruะhalas' revoliutsiia: na voennoi rabote (Moscow: Vysshii voennyi redaktsionnyi sovet, 1923), 1:394.

26. Oleg Ken, "L'URSS comme 'zone frontalière': la projection vers l'intérieur du discours de la frontière et des méthodes de contrôle territorial dans l'URSS des années 1920-1930," in Cœuré and Dullin, Frontières du communisme, 313-35. 
divided by boundaries into as many republic-nations as necessary, was never a single whole. This was a source of concern among many Communist militants and leaders, for whom centralization was the best protection against nationalist deviationism. Lenin had already addressed these fears at the end of 1917: "We are told that Russia will disintegrate and split up into separate republics but we have no reason to fear this. We have nothing to fear, whatever the number of independent republics. The important thing for us is not where the state border runs, but whether or not the working people of all nations remain allied in their struggle against the bourgeoisie, irrespective of nationality." 27 Admittedly, his position would eventually evolve, particularly in view of the failed revolution in Finland in early 1918. Over the course of the civil war, outside assistance from the Red Army sometimes helped destiny along, especially in the Caucasus. However, the decision to send the Eleventh Army into the territory of the Republic of Georgia on February 15, 1920 was taken after a great deal of hesitation, and was immediately justified as an act of legitimate defense against the British, who might have been considering using Georgian territory in their combat against the Republic of Soviets. The tendency to resort to military conquest, which had accelerated at the end of the civil war, did not change the fact that expansion was dependent upon the establishment of poles of proletarian sovereignty that subsequently requested to be associated with the founding polity. The territories acquired in this way were only rarely integrated directly into the motherland of the Russian revolution. In neighboring states, however, the opposite situation prevailed. In Poland, for instance, the idea of the nation-state fueled the will to integrate the Belorussian and Ukrainian borderlands, which had been conquered during the war against Russia, without granting them any autonomy.

In fact, not only did the Bolsheviks' undertaking, which has long been portrayed as essentially centralizing, adopt the nationality principle, but their conception of the notion - in contrast to that of the negotiators at Versailles-was not a unitary one. For the Bolsheviks, "to put autonomy into practice" was not "to tear the state apart." ${ }^{28}$ Unintentionally and unwittingly, they thus acted as more realist heirs to the complexities of empire than the Allies who had gathered in Paris in 1919. Autonomy and even independence, along with their corollary-the principle of association between nations-could, so they thought, prove to be remarkable instruments of revolution.

Nonetheless, there is no question that unified action between the republics developed during the civil war. It was considered a necessity because of the state of war and the supposedly greater efficiency of a single command structure.

27. Vladimir I. Lenin, "Speech At The First All-Russia Congress Of The Navy" (delivered November 22, 1917 and published as a pamphlet on December 5), in Lenin's Collected Works (Moscow: Progress Publishers, 1972), 26:341-46.

28. The expression is from Robert Redslob, Le principe des nationalités: les origines, les fondements psychologiques, les forces adverses, les solutions possibles (Paris: Librairie du Recueil Sirey, 1930), 190. 
Cooperation in terms of supplies and military operations began in spring 1919, and partisan connections were naturally the main driving force. On May 4, 1919, a directive addressed to the "friendly republics" established military subordination to the RSFSR and divided the territory of each republic into military regions. On June 1, 1919, a "single front" for the various republics was decreed. But the republics were reluctant to give up their prerogatives. In the case of Ukraine, for instance, the formal agreement on military and economic union with the RSFSR was only signed in late 1920, and Trotsky complained of the constant interference of the Ukrainian War Commissariat in the handling of operations. Each republic, moreover, retained the attributes of sovereignty. In early 1919, before Anton Denikin's victorious offensive temporarily called everything into question, the Bolsheviks thus supervised the creation of the Lithuanian-Belorussian Soviet Socialist Republic, or Litbel-based in two cities under the control of their partisans, Minsk and Vilnius-while the Ukrainian Soviet Socialist Republic (Ukrainian SSR) was established in Kharkov. Though their control over their territory remained problematic, these republics were devised as alternatives to the existing anti-Bolshevik and/or nationalist powers. ${ }^{29}$ From the moment of their foundation, some of their actions were highly symbolic assertions of their full sovereignty. In late February 1919, representatives of Litbel, followed in early May by those of the Ukrainian SSR, proposed the establishment of mixed commissions in order to delimit their borders with Piłsudski's Poland on the one side and the Western Ukrainian People's Republic set up in Eastern Galicia on the other. ${ }^{30}$ In 1921, however, the RSFSR became the sole interlocutor in numerous international negotiations after the other republics delegated their powers to it (whether under the Treaty of Riga or the Genoa Conference). During the negotiations that would lead to the formation of the USSR, the Soviet republics set up in the borderlands retained certain important aspects of sovereignty, while others were delegated to the federal authorities. These republics were thus seen as partners within the Federation that could also, by virtue of their position, serve as outposts of the national revolutionary emancipation of oppressed peoples. They also represented border guards, acting as buffer zones around revolutionary Russia. Thus, on the western borders in the mid-1920s, the Petrograd and Pskov regions were virtually the only areas of the Federal Republic of Russia to border directly on the newly independent states of Finland, Estonia, and Latvia. Lithuania was separated from Belorussia and Russia by the Grabski corridor, a strip of Polish territory extending to the northeast. The demarcating line of the Dniestr River, the only western border that was not recognized, lay along the frontier of Ukraine and not Russia.

29. The Litbel only lasted until May 1919, but its legacy was twofold: the formation of the Belorussian Soviet Socialist Republic, on the one hand, and Soviet support for an independent Lithuania in the face of Polish opposition, on the other. See Timothy Snyder, The Reconstruction of Nations: Poland, Ukraine, Lithuania, Belarus, 1569-1999 (New Haven: Yale University Press, 2003), 60-63.

30. Jerzy Borzecki, The Soviet-Polish Peace of 1921 and the Creation of Interwar Europe (New Haven: Yale University Press, 2008), 20. 


\section{The Bolsheviks and Territory, or The Art of Unfinished Business}

During the negotiations for peace treaties with neighboring states, the desire to break with the imperial heritage led to demonstrative gestures of goodwill and territorial concessions. The experience gleaned from Brest-Litovsk provided a method for a state that found itself in a position of weakness but imbued with a conquering ideology: it could provisionally cede ground without abandoning the medium-term objective of spreading the revolution. In the aftermath of the civil war and given the urgent need for economic reconstruction, commercial issues encouraged Russia to make generous territorial concessions. In negotiations over the peace treaty with Estonia, the Soviet delegation thus agreed to cede part of the Kingisepp district (a strip of 10 to 20 kilometers to the east of the Narva River) and the district of Pechory, which until then had formed part of the provinces of Petrograd and Pskov. ${ }^{31}$ In return, Russia obtained the exclusive use of warehouses in the main ports in order to relaunch trade with Europe, which had suffered considerably from the coastal blockade since $1918 .{ }^{32}$ Some members of the military disapproved of a boundary that did not follow river courses. On the other hand, the Russian minorities who found themselves on the Baltic side of the new border provided fertile ground for Communist propaganda.

With the Finns, the territorial question was complicated, and mutual political mistrust was extremely strong. In the context of armistice negotiations and the subsequent Treaty of Tartu, no party was willing to cede an inch of territorial ground. Chicherin proved to be a worthy heir to the diplomatic traditions of the old regime and refused to relinquish Petsamo despite the insistent demands of the Finns, to whom Alexander II had already promised to cede this port on the Arctic Ocean. There was further contention in Eastern Karelia over the parishes of Repola and Porajärvi, which were asking to be attached to Finland-for the Russians, changes to the border in this region represented a threat to the Murmansk railway. However, such demands and counter-demands are part of any negotiation process. The real issues at stake for the Bolsheviks were quite different, notably a favorable navigation regime in the Gulf of Finland and neutralization of the islands. It was Jan Berzin, head of the delegation in Tartu, who asked the crucial question: "What is more in our interest, peace with Finland and open access to the Baltic or holding on to Petsamo?" 33 Nor did a return to the exact line of the former administrative border between the provinces of Vyborg and Saint Petersburg pose a particular problem for the Bolsheviks at that moment, even if there

31. Andrei V. Sabanin and Viktor O. Broun, eds., Sbornik deistvuiuschikh dogovorov, soglashenii i konventsii, zakliuchennykh s inostrannymi gosudarstvami, vypusk 1-2. Dogovory vstupivshie v silu do 1/1/1925 (Moscow: NKID, 1935), 216-18.

32. Ibid., 229.

33. Arkhiv vneshnei politiki Rossiiskoi Federatsii (AVP RF), 0135/3/1/103, pp. 3-5, cited in Aleksandr I. Rupasov and Aleksandr N. Chistikov, Sovetsko-finliandskaia granitsa, 1918-1938 (Saint Petersburg: Evropeiskii Dom, 2000), 67. 
were already rumblings in some parts of the military that ratifying a border coming within 30 kilometers of Petrograd represented a security threat. The business of border lines was seen as provisional. However, their Finnish neighbors, anxious to demarcate the border once and for all, took quite the opposite view. From the Soviet perspective, the real issue was pursuing the fight against the government in Helsinki. Lenin and Chicherin helped the Finnish Communists who had fled to Russia to organize the Karelian Workers' Commune (July 1920), and later the Autonomous Republic of Karelia (1923). Their leader, Edvard Gylling, dreamed of a model border republic that would serve as a springboard for the future revolution in Scandinavia. ${ }^{34}$ Hence, when the Finns demarcated the border in the far north unilaterally and too far east in 1921, Chicherin's protests were not aimed at correcting a border that was disadvantageous to the Soviet fishermen of the Gulf of Vayda-Guba on the Arctic Ocean. Rather, they represented a tool of agitation against Helsinki. Yuri Markhlevski, one of the negotiators of the Treaty of Riga and head of the Russian delegation on the Russo-Finnish Central Mixed Commission, superciliously mocked the territorial stubbornness of these "hyperborean cave dwellers." 35

Contrary to what might be expected, the Russian-Polish discussions over the Treaty of Riga followed fairly similar lines, despite even greater mistrust between the parties. Admittedly, the liberal posture adopted was primarily a tool of political agitation, used in particular by Karl Radek after October 1920 in order to minimize defeat. Distorting the facts, the Bolsheviks thus claimed to have made a present of the provinces of Chełm and Białystok to the Polish masses by accepting a border lying even further to the east than that proposed by Lord Curzon on December 8, 1919. However, this was not just posturing. The correspondence between Joffe and the members of the Politburo during negotiations with Warsaw from 1919 to 1921 show that the Bolsheviks never made territorial claims the main thrust of their policy, whether before the war, at the time of their greatest victories from July to August 1920, or at the hour of their defeat in October. ${ }^{36}$ There were divergences and debates within the leadership, but these never concerned where the border should run. Instead, the concern was over the most effective means of ensuring the security of the revolution and its future expansion. At the time, Trotsky and Chicherin were in favor of accepting British mediation, whereas Nikolai Bukharin and Lenin continued to believe that the immediate sovietization of Poland was possible. ${ }^{37}$ They all shared a common objective-the demilitarization of Poland-but differed as to the solution. On several occasions, parallels with

34. Nick Baron, Soviet Karelia: Politics, Planning and Terror in Stalin's Russia, 1920-1939 (New York: Routledge, 2007), 21.

35. Cited in Rupasov and Chistikov, Sovetsko-finliandskaia granitsa, 77-78.

36. Ivan I. Kostiushko, ed., Pol'sko-sovetskaia voina 1919-1920: ranee ne opublikovannye dokumenty i materialy (Moscow: Russian Academy of Science/Institut slavianovedeniia i balkanistiki, 1994).

37. Ivan I. Kostiushko, "Popytka sovetskoi Rossii v 1920 razrushit' versal'skuiu sistemu mira," in Vostochnaia Evropa posle Versalia, ed. Ivan I. Kostiushko (Saint Petersburg: Aleteia, 2007), 163-86, here p. 167. 
the Franco-German border were drawn. Although the Treaty of Versailles was vilified in propaganda, when it came to reparations and disarmament obligations, or to the creation of a neutral zone separating the two former enemies, its example was strongly present in the negotiations as long as the Bolsheviks still had the upper hand. Moreover, the Bolsheviks, faithful to their internationalist project, were not against the idea of leaving substantial national minorities in Poland. Indeed, with two Belorussias, one on either side of the border, and two Ukraines, there were international, revolutionary, and irredentist levers that could, so it was hoped, be used to the advantage of Bolshevism. To this end, two clandestine Communist parties_one Ukrainian, the other Belorussian-were founded, both active in eastern Poland and run from Kiev and Minsk. ${ }^{38}$

Counterpointing these territorial settlements was the nonsettlement of the Bessarabian question. This was the only lost territory on which the discourse remained unchanged from 1919 to 1940. One might ask why Soviet leaders stubbornly refused to recognize Romania's annexation of the region, despite being prepared to cede territory elsewhere. ${ }^{39}$ The essential reason seems to be that it was not a new state resulting from the collapse of the Russian Empire. From the Bolshevik point of view, Romania's takeover of Bessarabia was a matter not of a people's right to self-determination, but of imperialist annexation. Bolshevik inflexibility on this matter was also commensurate with the harm done to the revolution by the Romanian army, the counterrevolutionary force that had crushed the soviets in Hungary and taken advantage of the civil war to occupy Bessarabia.

The Bolsheviks thus often granted the new national entities resulting from the emancipation of the non-Russian peoples of the empire the territory they claimed. This was true of Ukraine and Belorussia, which ultimately became republics of the USSR, but also of Finland and the Baltic states, which remained independent and-contrary to the hopes of the Bolsheviks-were not transformed into Soviet republics. It is important here to stress the need to view the negotiations over territorial limits as a whole and to call into question the overly rigid separation between the internal and the external history of the USSR's formation. Were the negotiations that took place between the Ukrainians, the Belorussians, and the Russians over the delimitation of the borders between the republics ultimately that different in nature from those between the Estonians, the Finns, and the

38. Communist activity in Poland was also coordinated by the Polish bureau created at the time of the Russian-Polish war: see Ivan I. Kostiushko, ed., Pol'skoe biuro TsK RKP (b) 1920-1921 gg. (Moscow: Russian Academy of Science/Institut slavianovedeniia i balkanistiki, 2004).

39. Very few studies or sources on the Bessarabian issue are available. The following book was written before the archives were opened: Nicholas Dima, From Moldavia to Moldova: The Soviet-Romanian Territorial Dispute (Boulder/New York: East European Monographs/Columbia University Press, 1982). The documents published in the following books reveal very little about Soviet motivations: Sovetsko-Rumynskie otnosheniia. Dokumenty i materialy, vol. 1, 1917-1934 (Moscow: Mezhdunarodnye otnosheniia, 2000): Vladlen N. Vinogradov et al., Bessarabiia na perekrestke Evropeiskoi diplomatii: dokumenty $i$ materialy (Moscow: Indrik, 1996). 
Russians? Admittedly, the political balances were often radically different, but the Communists were no less vocal than their adversaries about national territorial claims and questions of sovereignty. Negotiations between the republics or between Russia and neighboring states were structured in a similar way, with the creation of joint commissions on border demarcation as well as the sharing and transfer of assets and property. A clearer understanding of the "external" treaties of Tartu and Riga could no doubt be gained by studying them in parallel with the "internal" treaties that established the Soviet Federation. ${ }^{40}$

With regard to territory, some nations were given preferential treatment by the Bolsheviks for tactical reasons. This was the case internally with Belorussia and externally with the Baltic states. Over the course of the 1920s, recriminations emerged among certain Russian Communists who felt their interests had been damaged by both internal and external borders that were overly favorable to nonRussians. ${ }^{41}$ On the other hand, it is interesting to note that possibilities for arbitration only existed internally. Procedures for mediation were in place for disagreements over borders within the USSR, with a central role attributed to the AllSoviet Central Executive Committee (V'TsIK). Thus, in April 1924, the Republic of Belorussia and the region of Pskov (which at the time shared the former Vitebsk region) acrimoniously laid claim to two adjacent territories situated on the Latvian border, each for different reasons. An arbitrator appointed to work out a compromise found mainly in favor of Belorussia and against the Russian authorities in Pskov. ${ }^{42}$ No such arrangements existed when the demarcation of an international border was concerned, since Soviet Russia neither recognized nor was recognized by the League of Nations before 1934, and so was not involved in any recourse to this body. Protests made to the League's Council, such as the Finnish complaint of 1921, therefore remained unilateral. As a result, bilateral litigation dragged on indefinitely: some parts of the border between Finland and the USSR on the Karelian Isthmus, for instance, were still not demarcated in the mid-1930s, since there was no third party capable of resolving the issue in the face of divergent opinions and delaying strategies.

The formation of the USSR into a federation in 1923 was the next stage in this construction process. Each republic-nation (Ukraine and Belorussia at the federal level; the Commune of Karelia or the Moldavian SSR at the subfederal level, to mention just the national entities on the western border) was delimited by boundaries that had been negotiated with neighboring republics or regions within a political, military, and economic space that itself remained pan-Soviet. The territorial concessions made in treaties meant that each soviet republic could potentially become a revolutionary "Piedmont" for the national minorities in neighboring countries-a sign that the status quo was not meant to last. 


\section{The Border Zone as a Joint Modality of Sovereignty Assertion}

It seems reasonable to wonder whether this early Bolshevism did not risk being watered down once the "New Economic Policy" (NEP), with its imperatives of peaceful coexistence, was introduced. Questions about the norm-compliant component of Soviet attitudes are all the more pertinent since, once they had become statesmen, the Bolsheviks shared some of the preoccupations of their class enemies. Moreover, the problems that arose in the aftermath of the war could only be solved through consultation with the authorities in adjacent territories. Besides negotiations over peace treaties, there was the flow of refugees and the spread of epidemics to contend with, along with a minimum of cooperation in policing required to suppress banditry. ${ }^{43}$ The ideological war, combining class struggle and nationalist sentiment, was provisionally put to one side-though not abandonedand it was in this context that attempts were made to co-construct a relationship between neighbors along the borders.

Its scale was that of the border zone. On the Bolshevik side, the term originated in the experience of the civil-war fronts that coincided with the temporary borders of the soviets' territory. Units of military border guards had been stationed in these areas since 1918 with the mission to stem the flight of capital-in this particular instance, Tsarist aristocrats' gold and jewelry. ${ }^{44}$ In the directives and memoranda issued by the Red Army, the Cheka, and the border guard corps, a semantic shift can be observed over the course of the civil war: from prifrontovaia polosa to prigranichnaia polosa, or from "front zone" to "border zone." The notion of protecting the border zone and its inhabitants was already present in the decree on guarding the border issued on May 28, 1918, before the boundary had even been defined. ${ }^{45}$

In the aftermath of the war, this zone was the focus of special attention. The aim was to keep the peace and ensure public order, as well as to cooperate with the neighboring state while keeping a close eye on it. Within it, the sovereignty of one state or the other was measured in quotidian matters and permanent interactions, and the allegiance of the population was a very concrete question. There was competition between states over the currency in use, the police force capable of reestablishing order, the courts whose jurisdiction would be effective, the customs inspection regime, and the conduct of administrative investigations. Thus, when

43. Nick Baron and Peter Gatrell, eds., Homelands: War, Population and Statehood in Eastern Europe and Russia, 1918-1924 (London: Anthem Press, 2004).

44. On the origins and evolution of the Soviet border guard, see Sabine Dullin, "Les protecteurs : le rôle des gardes-frontières dans la surveillance des frontières occidentales de l'URSS (1917-1939)," in Cœuré and Dullin, Frontières du communisme, 379-405.

45. Rossiiskii Gosudarstvennyi Arkhiv Sotsial'noi i Politicheskoi Istorii (hereafter "RGASPI"), Dzerzhinsky collection, 76/3; Evgenii D. Solov'ev and Aleksandr I. Chugunov, eds., Pogranichnye voiska SSSR 1918-1928: Sbornik dokumentov i materialov, vol. 1 (Moscow: Nauka, 1973); and Dekrety Sovetskoi vlasti (Moscow: Gos. Izd-vo polit.lit-ry, 1959), 2:331. 
the Soviet authorities took over the enquiries launched by Jewish associations to document the pogroms that had occurred during the civil war, they reinforced the Jewish villagers' impression that they were the only authorities likely to protect them and give them justice. In the Mozyr district on the border between Poland and the Belorussian Republic, for instance, 3,600 people had given statements before March 15, 1921, and were registered as victims. ${ }^{46}$ Similarly, in spring 1921, local Soviet authorities in the border zone were instructed to register declarations of losses of hay and seed suffered by inhabitants as a result of the creation of the new border. ${ }^{47}$ The Soviets were thus able to present themselves as spokesmen for peasants stripped of their property by the Polish state and promised to raise the question in the Soviet-Polish Mixed Conciliation Committee.

These gestures, however, proved relatively ineffectual given the extent of ambient chaos and the authorities' inability to control the zone. The gold ruble faced an uphill struggle against the dollar, with which purchases of contraband goods were still being made in Minsk as late as $1923 .{ }^{48}$ Along the new European frontier of the Soviets' country, the civil war was prolonged in the form of lowlevel skirmishes and reprisals. Disarmament of the border zones meant putting a stop to the activities of the armed bands that paid little heed to the demarcation line and could always find refuge and support on one side or the other. The Soviet authorities had to contend with a loose-knit group of anti-Bolshevik units ranging from Ukrainian regiments commanded by Simon Petlyura and Yuri (Yurko) Tyutyunnyk to resistance groups in the Belorussian borderlands led by Stanisław Bułak-Bałachowicz and Boris Peremykin. The army led by Boris Savinkov, based in Poland, and the insurgents in Eastern Karelia also kept the guardians of Soviet order busy on the fringes of the territory. Many peasants, fleeing requisitions and seeking to escape conscription, had taken advantage of the civil war to join resistance groups, and they too were reluctant to disarm. Finally, banditry was a reality and thrived on the new opportunities offered by smuggling. Violence was therefore an everyday occurrence, and cooperation was needed to put an end to it.

\section{Mapping the Interstice for Better Control: The Establishment of Buffer Zones}

Within the framework of the various armistices and peace treaties, attempts were made to establish an arrangement for joint management of the border zone. As in other parts of Europe, the agreed solution was to establish zones that were neutral

46. NARB, 4/1/671. On the history of this vast survey documenting the pogroms of 19081922, see Lidia Miliakova, ed., Le livre des pogroms. Antichambre d'un génocide. Ukraine, Biélorussie, Russie, 1917-1922, trans. and ed. Nicolas Werth et al. (Paris: Calmann-Lévy, 2010). See also Thomas Chopard, Le Martyre de Kiev. 1919. L'Ukraine en révolution entre terreur soviétique, nationalisme et antisémitisme (Paris: Vendémiaire, 2015).

47. Declarations made by individual claimants had to include information under five headings: place of loss, name of complainant, reason for loss, nature and volume, and 
and, later, demilitarized. ${ }^{49}$ These areas were recorded on maps and shown as two hatched strips situated on either side of the border line. The first neutral zone was established for a period of two years by the February 1920 peace treaty between Russia and Estonia. The only forces entitled to patrol the area were regular units of the border services and those involved in maintaining public order. ${ }^{50}$ All fortifications, observation posts, military installations, depots, and airfields were forbidden, and boats with military equipment were banned from lakes forming part of the border. However, the clause stipulating the disarmament of the border zone was simply a further security demanded within the global logic of the disarmament of neighboring territories. Indeed, all the treaties signed in 1920-1921 contained clauses stipulating the disarmament of so-called foreign and hostile troops throughout the adjacent territory, and mixed commissions were established to ensure their implementation. In the ensuing years, Soviet diplomats constantly demanded that the surveillance of Russian émigré organizations abroad be strengthened. The same precise territorialization of a buffer zone figured in negotiations with Finland and Poland. Here again, the clauses demanded by Soviet negotiators, stipulating the disarmament of hostile foreign forces throughout Finnish and Polish national territory, were complemented by demilitarization measures explicitly concerning the border zone.

The Russian-Polish armistice of December 4, 1920 created a neutral zone. It extended 10 kilometers on either side of the border line, with even stricter rules applicable to the first 3 kilometers. Abolished on April 6, 1921, after the Treaty of Riga was signed, this zone so impressed itself on people's minds that they still referred to certain villages as being in the neutral zone a year later. ${ }^{51}$ Indeed, it possessed specific characteristics, and in terms of public administration it was not integrated into the rest of the territory. The area had no soviets or executive committees, which now formed the local authorities in the rest of the territory, but still retained its local revolutionary committees, provisional bodies that perpetuated the civil war atmosphere. Border railway stations, such as the one in Negoreloe, were jointly controlled by Polish and Russian units, with Polish and Soviet soldiers patrolling the same border-control path. Theoretically, coordination was also envisioned in order to combat the zone's two scourges of banditry and desertion.

More than cooperation, however, everyday interaction gave constant cause for loud protestations of sovereignty in the face of the enemy partner's attempts at interference. Each party interpreted the letter of the armistice agreement in its own way. Pointing to the articles forbidding a military presence, requisitions, violence against civilians, or acts hostile to the opposing party in the neutral zone, the Poles kept a tally of the requisitions made by armed detachments in villages lying in the Soviet-controlled neutral zone, along with a record of revolutionary

49. Sabanin and Braun, Sbornik deistouiuschikh dogovorov, 57, 91, and 119.

50. The total size of the armed forces (police and border guards) allowed in the two zones was limited to five hundred men overall, that is, a maximum of forty men per verst of border during the first six months and thirty thereafter ( 1 verst $=1,066.8$ meters $)$. 51. NARB, 693/1/1, 24; 6/1/18a, p. 2. 
propaganda tracts they considered anti-Polish. For their part, the Soviets kept detailed accounts of the gangs operating out of the Polish neutral zone, recording their numbers and listing their leaders. They logged cases of looting and violence and noted down every attack upon Communists, Soviet officials, and food-supply brigades. This information, collected via the intelligence services in the border zone, was then dispatched in two directions.

First, it was used as ammunition in an acrimonious diplomatic exchange. The data on border-zone activity, provided by military revolutionary committees and the Minsk District Headquarters' anti-banditry commission, was thus reused by diplomats in notes of protest, which often contained very precise information on names and places. ${ }^{52}$ These notes, which were penned in the style of police reports and described the dangerous zone along the border in detail, never failed to offend the Poles' sensitivity to any slight to their sovereignty. They made it seem as if the Soviets were criss-crossing their territory. In the note sent by Chicherin to Poland on April 11, 1921, for instance, it was observed that Bułak-Bałachowicz and Peremykin's Belorussian counterrevolutionary committee had moved into Nesvizh and that gangs had emerged from Baranovicze, Nesvizh, and Luninets, while further south active Petlyurist units were operating out of Ostrov, Rovno, and Shepetovka. ${ }^{53}$ Similarly, a note from the government of Soviet Ukraine dated April 16 expressed concern about anti-Bolshevik activity, mentioning an army forming at Tarnopol and the presence of headquarters for armed Petlyurist gangs preparing to make incursions across the border from Rovno, and protesting about the support given to them by the Polish authorities. This information was subsequently used to mobilize village populations. Indeed, the local authorities-in particular the militia entrusted with public order-were instructed to inform the population through public meetings, declarations, and press articles of the tenor of the representations made to Poland over breaches of the Riga agreement. ${ }^{54}$

On the Soviet-Finnish border, the process of territorializing the border zone was even more refined. As early as the first armistice negotiations in 1920, the Finnish side proposed the establishment of a neutral zone. The aim was to obtain the status of a demilitarized zone for Eastern Karelia, to which some political forces in Finland laid claim, extending all the way to the Murmansk railway. The Soviet delegation refused this excessively one-sided proposal but recognized the interest in setting up, on either side of the border, a neutral zone some 10 kilometers wide, enlarged at certain points to include the most contested area-the parishes of Repola and Porajärvi.

53. The Russian and Ukrainian governments sent a succession of notes on April 11 and 16, May 3 and 26, and July 4, with Polish denials issued on April 19 and May 23: see Dokumenty Vneshnei Politiki SSSR (hereafter "DVP SSSR") (Moscow: Politizdat, 1960), 4:62, 96, 139, and 203.

54. NARB, Circulars issued by the NKVD, Minsk, March 1923, 1715/2/35. 
Map 1. Buffer zone between Finland and the RFSFR (June 1, 1922)

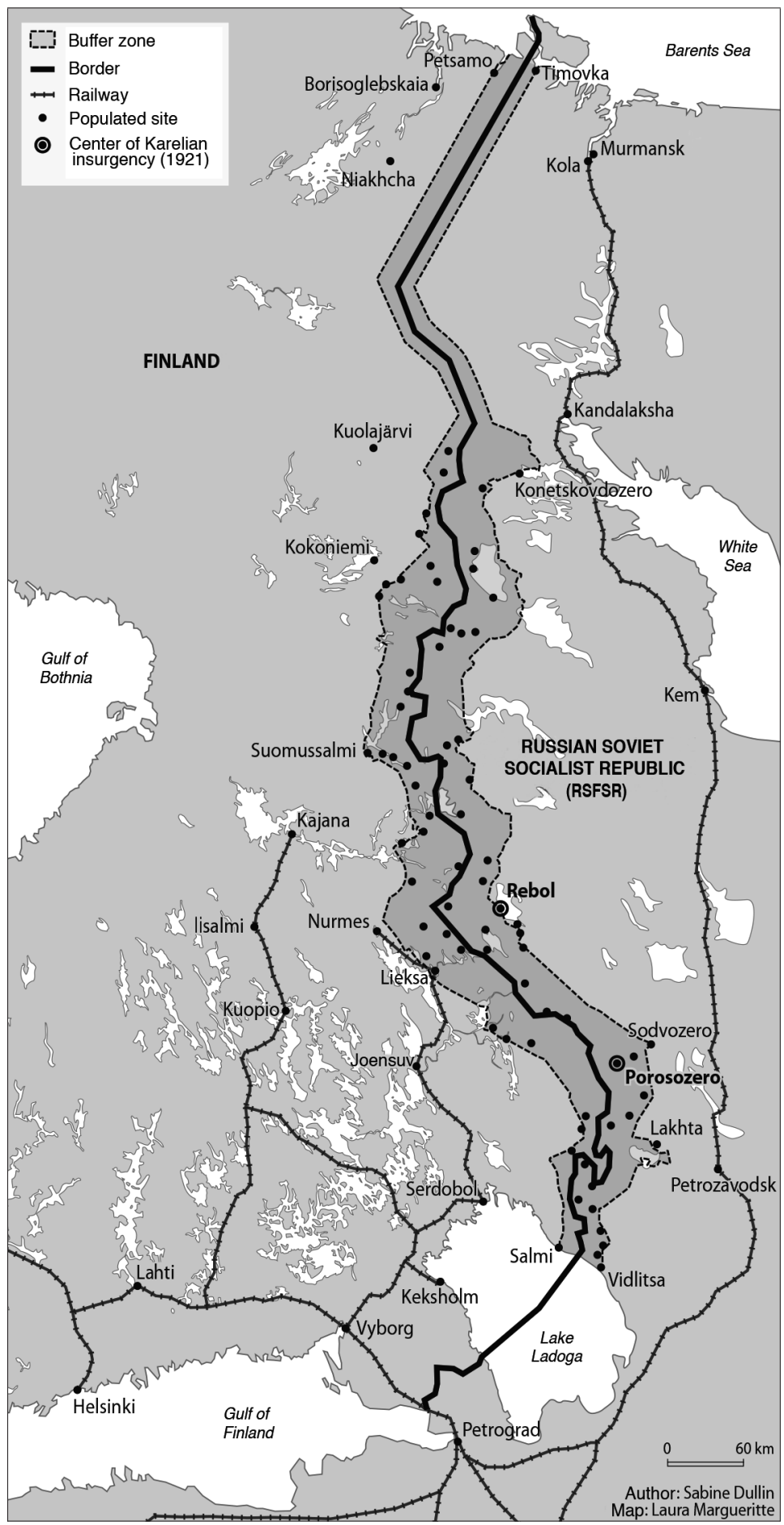


The buffer zone, as provided for in article 37 of the treaty and placed under the responsibility of the Russo-Finnish Central Mixed Commission, had to be hastily implemented in the spring of 1922. There followed a period-one of many to come-of Soviet concern about the border. The difficulty in putting an end to the insurrection in the border communes of Eastern Karelia during the winter of 19211922 was compounded by apprehension about the possible creation of an antiSoviet military alliance when Latvian, Estonian, and Finnish delegates held a conference in Warsaw from March 13 to 17 . It was in this climate that the convention delimiting two parallel zones running from the Arctic Ocean as far as Lake Ladoga was signed on June 1, 1922. According to the terms of the agreement, these zones were between 10 and 16 kilometers deep on either side of the border, depending on the location, although the attached map showed a much larger area. They were to be demilitarized, and only 2,500 border guards and around a hundred militiamen or police officers were allowed to patrol on each side. The negotiations launched the first of many discussions about what the expression "militarized organization" covered-an argument that was to continue throughout the 1920s between the Soviets, who demanded the disarmament of the civic guards (Schutzkorp), and the Finns, who were intent on having members of the Communist Youth Organization included in the calculations. ${ }^{55}$ This debate was reignited on the occasion of the Preparatory Commission for the Geneva Disarmament Conference and, with the development of Fascist paramilitary militias, became an international debate in which Soviet diplomats were actively engaged. ${ }^{56}$

The text of the convention should unquestionably be seen as a victory for the Soviet side. Its signatories saw it, a posteriori, as "a guarantee against KareloFinnish activism." 57 The Finnish civic guards and the RSFSR's voluntary surveillance brigades were forbidden to come within 3 kilometers of the border or combine several patrols into a single group. Moreover, the Finnish government undertook to remove from the border zone the leaders who had participated in the armed struggle in Eastern Karelia and all Karelian refugees who were old enough to bear arms, apart from those who had family ties to the area or had clearly demonstrated their peaceable intentions. Thereafter, the Soviet delegation in Helsinki doggedly made sure that this measure was applied. On July 15, the Finnish Interior Ministry instructed the governors of the border provinces to count the numbers of refugees and implement the order expelling the categories specified in the agreement from the border zone. In early September, the governors reported that there were no refugees left in the border zone, except around Kuusamo. This did not put an end to the matter as far as the Soviets were concerned. At the request of the Helsinki government, which was itself under pressure from the embassy of the USSR, the

55. In the mid 1920s, there were about two thousand civic guards drawn from local inhabitants of the border zone.

56. Certain aspects of this issue are discussed in Sabine Dullin, Men of Influence: Stalin's Diplomats in Europe, 1930-1939 [2001], trans. Richard Veasey (Edinburgh: Edinburgh 
ministry submitted a memorandum listing the reasons for the delay in expelling Karelian refugees.

As it was implemented, the zone satisfied the Bolsheviks' security concerns but not the defense objectives of the Finnish army, which had expressed its preference for another project involving the limitation of weapons and armed forces inside the "border territories" - a group of districts that could extend as far as 150 kilometers into Russia and which encompassed the whole Karelian Isthmus. While the Finns failed to obtain this guarantee against a possible Soviet mobilization and attack, the demilitarization that was finally achieved along a narrow strip of territory fully answered Soviet concerns about diffusing political contestation in the fertile soil of the opposing border zone and ensuring the protection and inviolability of the border. However, not all of the Soviet diplomats' demands were met. In particular, the Finnish side refused to submit to Soviet demands that the neutral zone encompass a number of villages that the State Political Directorate, the Gosudarstvennoe Politicheskoe Upravlenie (GPU), considered to be the rear bases of the counterrevolutionary insurrection.

The idea was to enable cooperation in maintaining public order and thus in pacifying the border zones. In doing so, the neighboring states recognized one another's right to carry out surveillance and gather information in the adjacent foreign zone, where they would post intelligence agents. The clauses on border disarmament thus provided a permanent justification for interference in the local affairs of the neighboring state, and the Soviets were quick to take up this opportunity. Acting as police informers, they expected the authorities in the adjacent state to clean up the border zone and expel their adversaries from it. Regular diplomatic protests about the neighboring state and its failure to meet its disarmament obligations were thus answered most effectively in the clauses concerning the border zone, which was easier to control than the rest of the territory.

\section{Joint Handling of Border Incidents}

In 1921, transborder surveillance of the border zone led to new structures for cooperation. A mixed commission charged with managing incidents along the Soviet-Polish border was thus established on June $1 .^{58}$ Each incident was recorded in two reports drawn up by the border commissars using information supplied by the border guards and based on statements made by inhabitants. In Soviet territory, the Commission for the Fight Against Banditry, created a few days earlier on the western front (May 22, 1921), was used to relay information.

58. The protocol concerned instructions for arbitration commissions dealing with border incidents, which were agreed between the representatives of the RSFSR, the Ukrainian SSR, and the Belorussian SSR on the one hand, and Poland on the other on June 1, 1921. The border was divided into five sectors in which sat five subcommittees made up of three members from each party. Meetings were held at least twice a month. The commission ceased to meet upon the formation of the USSR in July 1923. Diplomats negotiated a new agreement on border-conflict resolution as early as September 1923, though this was not signed until August 3, 1925. See DVP SSSR (1963), doc. 257, 8:464. 
Likewise, on the Finnish border five local control commissions were established under the auspices of the Central Mixed Commission to enforce disarmament of the zone. These commissions were tasked with the day-to-day handling of any incidents that might occur. ${ }^{59}$ In mid-September 1922, the president of the Central Mixed Commission, accompanied by the Finnish delegates, traveled to the border zone to familiarize himself with the area. He was struck by the complete lack of resources attributed to the border guards working in the Soviet part of the zone. Some members of the commissions, whose operations fell under the aegis of the Commissariat for Foreign Affairs, were agents working for the intelligence services. The Soviet representatives generally included an agent of the Counterespionage Directorate attached to the headquarters of the Red Army (Rawvedupr) and an agent of the GPU working at the local border post. In June, a decree issued by the counterespionage department of the headquarters of the Petrograd military district had ordered that these commissions be used to gather intelligence. However, a few months later, the Commissariat for Foreign Affairs reminded delegates that circumspection was required to avoid any sort of diplomatic complication. On the Finnish side, each inspection carried out in the Soviet zone was followed up with reports directed to the head of security in Helsinki. The main task of the commissions, then, was to verify that disarmament was implemented and, in case of any incident or violation, to lead an inspection and inquiry in the zone on the other side of the border. There were risks involved in carrying out these missions, since the pacification of the borderlands remained fragile. Indeed, the president and one of the Soviet members of the third border control commission were assassinated while carrying out an inspection on September 24, 1923. The ensuing investigations made it possible to identify the murderer, a Karelian refugee, whose extradition was subsequently demanded by the Soviets. ${ }^{60}$

Despite such hazards, the Soviet leadership considered this close arrangement a success. In a conference on disarmament held in Moscow on December 2, 1922, to which Russia invited delegations from its western neighbors (with the exception of Romania) and from its sister republics of Ukraine and Belorussia, the agreement was held up as a model for all land borders. ${ }^{61} \mathrm{~A}$ number of conventions were subsequently signed, in particular with the Baltic states. Most surprising, however, was the Soviet-Romanian document of November 20, 1923 "on the measures and means in view of the prevention and resolution of possible conflicts arising on the Dniestr River," since it represented an agreement between two countries with no diplomatic relations. ${ }^{62}$ In fact, the border itself, which was not recognized by Moscow, was never referred to as such in the agreement-only the Dniestr is

59. The role of the Mixed Control Commission was subsequently conferred upon a Russian-Finnish border committee chaired, for the Soviet area, by the first secretary at the Russian embassy in Helsinki.

60. DVP SSSR (1962), 9:481-84 and (1963), 7:391-92.

61. DVP SSSR (1962), 6:26. 
mentioned. The text, drafted according to the model of the Soviet-Finnish treaty, puts even greater emphasis on the prevention of border incidents. The accord anticipated four types of cases in which complaints could be lodged with the mixed commission and witness statements could be taken: shots fired from the opposite riverbank, actual or attempted crossing of the Dniestr without authorization, theft of goods, and smuggling.

However, this agreement did not grant the Soviets everything they had requested, notably the right of hot pursuit. On August 13, 1921, Chicherin and Rakovsky sent the following note to Demetriu Ionescu, the Romanian minister of foreign affairs: "Wishing to assist the Romanian authorities in liquidating the gangs that have formed in the territory of Bessarabia and Romania with the aim of carrying out acts of aggression against the Soviet Republics, the United Soviet Governments, taking into account the requirements of their military obligations and the security of the Soviet Republics, consider it necessary, when in pursuit of these gangs, and if they penetrate into the territory occupied by the Romanian authorities, to follow them into the said territory, informing the Romanian authorities thereof, so that these acts by the Ukrainian and Russian Red forces are not interpreted as hostile to the Romanian people and its government." 63 This demand, which represented a threat to Romanian territorial sovereignty over Bessarabia and was reminiscent of early nineteenth-century imperial practices, undoubtedly prompted the local Romanian authorities to sign an agreement provided it guaranteed Romanian territory against unilateral interventions of this sort.

These committees for the resolution of border incidents represented a unique form of transborder police and diplomatic collaboration between ideologically hostile entities. While they may have contributed to the pacification of the borderlands between 1921 and 1924, they above all enabled, in a bilateral and reciprocal sense, the close everyday surveillance of a neighboring state and the patrolling of its territory. Yet this indiscretion in the border zone was initiated in the name of the defense and inviolability of sovereign territory, and the documents produced by the commissions for settling incidents along the border thus furnish interesting source material for a study of its concrete, on-the-ground meaning.

In the doctoral thesis on borders he defended at the Sorbonne in 1928, Paul Geouffre de La Pradelle discussed the Romanian-Russian border regime put in place in 1923 and considered it as an example of "perfect modernity." In his opinion, the agreement over the Dniestr River was a solution reached through "good neighborliness," made with the aim of protecting the populations and without the need for territorial and diplomatic recognition between the two states. As such, he argued, it represented the victory of the "right of ordinary people." 64 While La Pradelle's highly optimistic, apolitical view of this agreement may raise a smile among historians of the USSR, it nevertheless reminds us of an essential fact: neighbor diplomacy is, or should be, primarily diplomacy in the service of inhabitants of the border zone. 


\section{Toward Exclusive Sovereignty: The Unilateral Choice of a Thick Border}

In the western borderlands of the new Soviet territories, most residents had never previously been inhabitants of a border region, and had only become so after the delimitation of the new states. The only citizens already accustomed to living on a border were those residing along the Zbruch River (the last remnant of the territorial limit between Austria-Hungary and Russia), and on the Karelian Isthmus, where the Duchy of Finland's administrative autonomy, including a specific customs regime, had facilitated a flourishing smuggling trade after its integration into the Russian Empire in 1809. It therefore took quite some time for the lived territory to be reconfigured by the border. The human specificities of these new borderlands, where everyday spaces did not coincide with the new political boundaries, encouraged the successor states to the three empires to sign bilateral agreements delimiting border zones in which specific rules on circulation and trade applied to inhabitants. ${ }^{65}$ Some of these provisions, in particular those concerning property, were only temporary. These "small-border" or "small-border-traffic" agreements, which were frequently annexed to commercial treaties, recognized the specificity of everyday life on the periphery of the new states and granted special permits and passes to the inhabitants of designated towns and villages situated within a strip of 10 to 15 kilometers. The limits of the zone and crossing points were defined on each side, as was the list of goods exempted from customs duties. In the case of certain emergency-related professions, such as doctors, veterinarians, and firefighters, the injunction of proximity could completely erase the border.

In the formative phase of the USSR, the organization of these small borders was just as necessary as it was elsewhere. However, there was one major obstacle to contend with: the problem of the monopoly on foreign trade, which was an integral component of territorial sovereignty. In 1922, Lenin, who was a staunch supporter of this principle, expressed concern about the gradual erosion of the monopoly and declared that he preferred to deal with specialized smugglers rather than the masses of peasants trading legally on the borders. ${ }^{66}$ Yet a series of the government's own decrees had provided for partial and provisional exemptions on certain borders, with the goal of developing the flow of import-export trade. In 1923, the notion of transborder relations was present in the legislative framework organizing the border zone. Under specific circumstances, it was possible to cross the border at customs posts or points designated by the border guard in order to trade on the other side of the boundary line.$^{67}$ At stake was the improvement of

65. League of Nations Treaty Series, vol. 97 (Geneva, 1929-1930), no. 2222, pp. 117-29. 66. "O monopolii vneshnei torgovli," letter from Lenin to Stalin on behalf of the members of the Central Committee, 13 October 1922, in Lenin, Polnoe Sobranie Sochinenii, 43:220. 
supplies in regions where endemic shortages of all essential commodities had resulted from both the destruction caused by war and the areas' remoteness from the principal centers and communication routes. Despite Lenin's objections, in the following years transborder trade relations included a decentralized component of private-sector and cooperative actors, in the interest of enabling reconstruction, discouraging the activity of smugglers, and improving living conditions in the border zone. Thus, until 1925 on the Estonian and Latvian borders, peasants were allowed to barter goods at stalls located within the area of 100-200 meters separating the Baltic border posts from their Soviet counterparts without being considered smugglers. ${ }^{68}$ Moreover, the border zone occupied a privileged position that set it apart from the rest of the territory, benefitting from credit facilities and especially customs-duty exemptions or reductions on a certain number of products, aimed at organizing the import of supplies. Most enclaved border districts in Karelia, therefore, were able to import from Finland certain goods approved by the Customs Tariffs Commission, on which duty was either halved or abolished. ${ }^{69}$ The list included such goods as coffee, leather, glazing materials, cutlery, agricultural implements, stationery, fishing nets, small livestock, and so on. Even the main centers of the 1921 Karelian insurrection were granted permission to benefit from imports and hence became reliant on the border trade linking them to Finland.

However, transborder economic links in the 1920s were not solely commercial. They also involved the traffic linked to joint usage of the territory. Ever since the formation of the Russian Empire's borders, certain transborder activities had been subject to regulation. These agreements guaranteed fishing, hunting, and grazing rights, provisional rights concerning property and its use in the border territory, and the right to frequent habitual places of worship now situated in a foreign country. ${ }^{70}$ With the new regime, the reordering of external relations with neighboring countries meant that the corpus of agreements needed to be completely rewritten: borders had changed and the Soviet state refused to maintain legal continuity with the previous Russian regime. Within the framework of the transitional Soviet international law drafted by Korovin among others, "technical" bilateral treaties were the only legally acceptable instruments in the reordering of the proletarian state's foreign relations. On November 11, 1925, the economy and law department of the Commissariat for Foreign Affairs assessed the conventions signed by Soviet Russia. They remained very few in number, illustrating the diplomatic isolation in which revolutionary Russia still found itself. Sixteen conventions approved in meetings of the Council of People's Commissars had been signed, twelve of which concerned the organization of transborder relations with adjacent

68. On February 21, 1925, an exchange of memoranda concerning the definitive closure of the trading counters on the Latvian border was annexed to the text of the draft agreement on the resolution of border conflicts between the USSR and Latvia, which was ultimately signed on July 19, 1926: see note 49, DVP SSSR (1963), 8:157.

69. GARF, 5446/8/496, pp. 3, 5, and 17-19.

70. Sbornik pogranichnykh dogovorov zakliuchennykh Rossiei s sosednimi gosudarstvami (Saint Petersburg: Ministerstvo Inostrannykh Del, 1891), 2-33. 
countries. These conventions dealt with the creation of mixed border commissions, the extradition of criminals, the usage of water and pastures along the border, navigation, border crossings, railways, and postal and telegraphic communications. It was necessary to ensure, for instance, that the Saami people could cross the Russian-Norwegian border to continue the transhumance of reindeer herds and to organize the log driving that was practiced as much by Balts and Finns as by Russians.

Nonetheless, it became immediately apparent that there was a contradiction and a discrepancy between this border diplomacy, intended to serve the economy and facilitate circulation in the border zone, and the Soviet border authorities' constantly reiterated objective to protect the territory. From this perspective, the implementation of the good-neighbor agreement with Finland is exemplary. In the wake of the Tartu peace treaty, the interweaving of Finnish and Russian territories made it necessary to sign a number of conventions regulating bordercrossing rights and regional economic activity, particularly fishing and seal hunting. ${ }^{71}$ These agreements raised concerns when they authorized the free circulation on Soviet territory of foreigners who had not been selected by the Communist parties, border guards, and Chekists of the GPU. The police authorities viewed these transborder relations, which might be thought unexceptional and even advantageous for the mutual prosperity of the societies involved, as an intrusion and a territorial violation. Soviet negotiators were therefore instructed to make the other party accept strict monitoring procedures regulating comings and goings across the border. The agreement of June 5, 1923 allowed Finnish boats free passage on the Neva - the only navigable river-as far as Lake Ladoga, the northern half of which fell within Finnish territory. But this agreement was accompanied by a series of restrictions demanded by the Chekists and the military of the Petrograd/ Leningrad region: boats were obligated to dock in Kronstadt, where they were inspected by customs officers; cargoes were sealed and radio aerials had to be disconnected upon entry into Soviet territory; a border guard had to be admitted onboard during passage through Soviet Russian waters and the ship's register inspected; the captain was held responsible for his crew and was forbidden to hire sailors whose Russian nationality had been revoked in accordance with the 1921 decree to this effect. It is clear that these measures had very little effect in the early 1920s, especially since the NEP allowed foreign businesses to acquire concessions for the exploitation of certain resources during the same period. ${ }^{72}$ However, this in no way undermines the fact that a policing-oriented approach was already firmly entrenched and imposed on all Soviet diplomats-even when they did not share it. It stemmed from a perception of the border as an interface between the proletariat's homeland and a capitalist outer world, which needed to be influenced but also guarded against. And reducing this interface meant first curtailing shared usage of the territory as much as possible. and Ulav Riste, eds., Sovetsko-Norvezhskie otnosheniia, 1917-1955 (Moscow: Ėlia-Art-O, 1997). 


\section{Map 2. Rights of passage for Finnish fishing boats along the Neva River (agreement of June 5, 1923)}

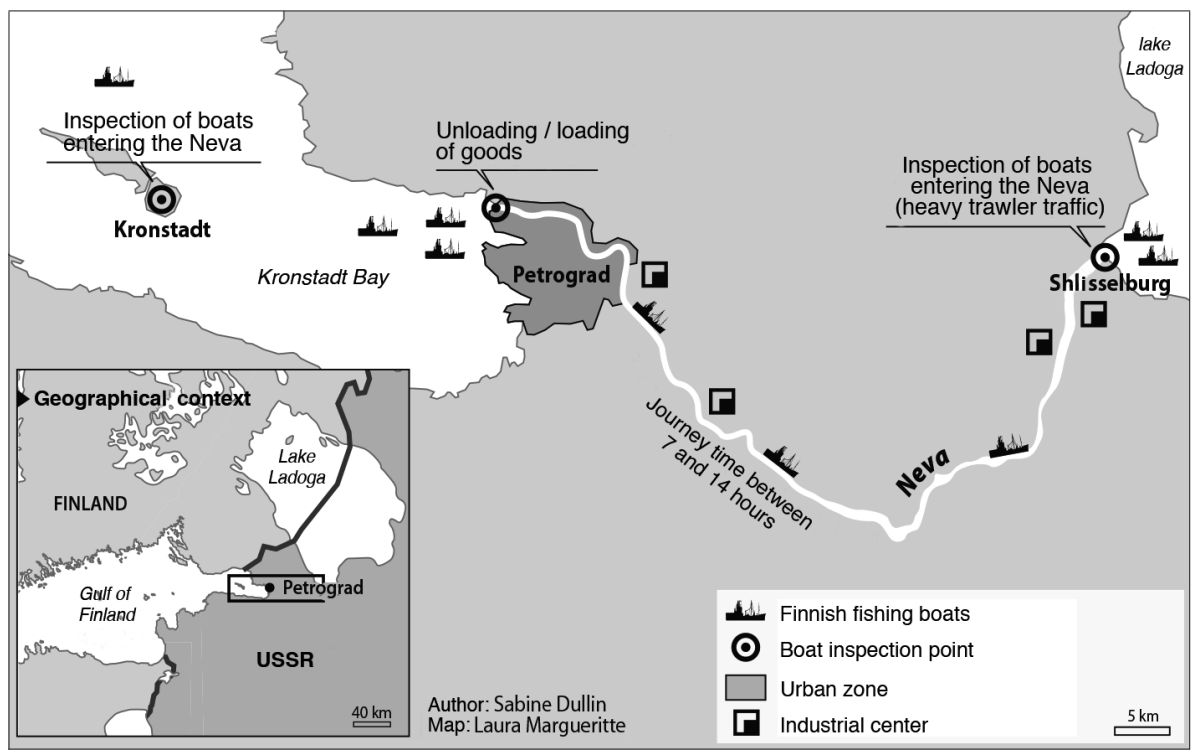

During the USSR's formation, protection of the territory also took the territorialized form of an internal border zone. It is legitimate to wonder about the roots of this concept, which was deliberated in the spring of 1923 by a committee of the Politburo that included Iossif Unshlikht, Viacheslav Molotov, Maksim Litvinov, and Radek. The establishment of this new zone on the edges of the national territory was integral to the shaping of the institutions and territory of the USSR. In the preamble to the Constitution, the creation of the USSR was justified by the need to present a "single front" in the face of "capitalist encirclement." The July decree on the border zone and the subsequent regulations issued to the border guard can be seen as a means of protecting the "single socialist family" by organizing a territorial "cordon sanitaire" of its own. ${ }^{73}$ However, the experience of the war also played a part in this administrative innovation. Indeed, the creation of the border zone went hand-in-hand with practices aiming to "cleanse" it and make it more reliable under what was perceived as a permanent threat of war. The first project presented by Unshlikht, the vice-president of the GPU, and considered unacceptable by the Commissariat for Foreign Affairs, reprised the geographic scale of the 150-kilometer-deep zone from which hundreds of thousands of Germans and Jews had been expelled to the interior in 1915, when the high command of the Tsarist army, at war with the central empires, suspected them of sympathizing with the 
enemy on ethnic grounds. ${ }^{74}$ The committee also invoked the precedent of the May 1919 relocation of all counterrevolutionary elements from the area of the front lying north of Petrograd. ${ }^{75}$ In the end, however, the scale adopted for the border zone was closer to that of the neutral zones created under the peace treaties and in which cleansing practices were validated by bilateral diplomatic arrangements. The inspiration for this zone is also to be found, although this is not explicitly acknowledged in the files that I have been able to consult, in the anti-smuggling measures dating back to the prerevolutionary period and the designated areas in which customs officers could pursue suspects and undertake searches during the prewar years. ${ }^{76}$

What then was this border zone like? It was made up of four bands of territory. After a 4-meter-wide strip that comprised the border itself, ${ }^{77}$ the first 500 meters were regulated by the GPU-controlled border guard, set up and structured at that time to mirror the border police of neighboring states. ${ }^{78}$ This space contained barracks and surveillance facilities, and building was strictly regulated and subject to threefold authorization by the Soviet executive committee, the border guard, and the military authorities, particularly in sectors considered strategic. The next 7.5 kilometers constituted the rear base for the activity of the border guards, who had full powers to check papers and carry out searches and confiscations. Finally, the right of hot pursuit inside the territory was extended to a zone some 16 to 22 kilometers deep (12 nautical miles on the sea borders). This border zone, so elegantly drawn around the edges of the territory in a sort of ideal geometrical construction, served as a double-door monitoring system for anyone entering or leaving the country. The targets of these border-policing arrangements were not set in stone. In 1923, the smuggler, the bandit, and the foreign intelligence agent were the three figures heading the list of "catches" in the border zone. Later, however, as regulations became even more punctilious and restrictive, individuals who illegally crossed the border or infringed border-zone regulations were added to the mushrooming category of "border violators." The aim was less to counter the threat of war than to establish close police surveillance of an interface that was now delimited internally. The 1923 decree instructed the regional executive committees to assist in drawing up large-scale maps of the border zones and to make them available to the commanders of the border guards. Over the following four years, a series of instructions subsequently laid down specific regulations on

74. Eric Lohr, Nationalizing the Russian Empire: The Campaign against Enemy Aliens during World War I (Cambridge: Harvard University Press, 2003).

75. This led to a first wave of deportations of so-called Ingrian populations living in the vicinity of Petrograd: see Vadim I. Musaev, Politicheskaia istoria ingermanlandii v kontse $X I X-X X$ veke (Saint Petersburg: Nestor-Istoria, 2001).

76. On the Tsarist legacy, see Dullin, La frontière épaisse.

77. In certain sectors where the border was inaccessible, the 4-meter strip containing the agreed border-control paths could be located up to 7.5 kilometers within the boundary line, in which case the regional executive committee was obliged to cede the neces- 
residence or short-term stays in these zones, on files to be kept on inhabitants, and on categories of the population deemed unreliable and targeted for expulsion.

Let us turn to Belorussia to track the practical application of these decisions. The decree on the border zone was only implemented in June 1924. Up to that point, the services of the GPU and the border guard had been instructed by their hierarchy to issue passes to inhabitants, but these orders were never implemented: the rules on entry into and residence in the border zone were too imprecise, the delimitation of the zone uncertain, and the inhabitants themselves uninformed. A close examination of the minutes of the meetings at the Minsk uewd level for 19231924 reveals numerous individual cases from the villages reporting the arrest of distillers, poachers, and unauthorized woodcutters, but almost no sign of persons being questioned by the police for residing illegally in the border zone. ${ }^{79}$ Between the level of the republic and the intermediary echelon, implementation was therefore a protracted process. The authorities of the Mozyr okrug, for instance, were slow to enforce the Belorussian decree of June 1924, and it was not until a year and a half later that the inhabitants were informed of the new arrangements. ${ }^{80}$ The republic's margin of maneuver should also be taken into account. The Belorussian authorities considered local factors and feasibility when incorporating the application of the decree into their own body of administrative legislation. The width adopted for the border zone was thus different: it measured 10 kilometers, with a so-called forbidden zone (zapretzona) of 250 meters. These dimensions corresponded more closely to the local memory of the neutral zone and to a decision made in February 1923 not to build within 250 meters of the boundary line in order to strengthen border protection and the fight against smuggling. ${ }^{81}$

The decree of June 20, 1924, which concretely organized the monitoring of inhabitants, made provision for a single legal document entitling citizens aged sixteen and over to reside and travel within the border zone. ${ }^{82}$ This was a card proving the bearer's identity, furnished by the district authorities and stamped by the nearest unit of the border guard. ${ }^{83}$ The district executive committees were thus entrusted with the task of making a census of all the inhabitants, checking their identity, and providing a copy of these lists to the border guard. To enter the border zone, all Soviet citizens arriving from the interior needed an entry visa issued by the district authorities and registered by the border guards. The objective of identifying and controlling all the inhabitants of the border zone is very clear

79. The administrative subdivisions were modified and their boundaries changed in 1923, at the time of the USSR's formation. At the intermediate level in a republic such as Belorussia, the $u e \approx d$ was replaced by the raion and the okrug. For the sake of convenience, I use the term "district" to refer to this intermediate administrative level. See NARB, 6/1/334.

80. NARB, 6/1/546, p. 121, decree of the Mozyr okrug executive committee, October 29, 1925

81. NARB, 6/1/175, p. 8, protocol no. 4 of the meeting of the Presidium of the TsIK of the Belorussian SSR, February 2, 1923.

82. NARB, 6/1/353, pp. 2-3.

83. Only authorities and judicial officials at the local, regional, and republic levels were exempted from the visa requirement. 
in these regulations. The files of the local archives, however, reveal a slightly different picture. Breaches of the rules were rarely punished (at most, a warning or a small fine) and even more rarely referred to a higher level. The militia, a republic-level institution, does not seem to have been particularly invested in monitoring the circulation of inhabitants in the border zone, which in any case was highly unpopular.

In contrast, the instructions on keeping files about and relocating suspicious individuals, which essentially fell under the remit of the GPU, a federal institution with a single command structure, were implemented more fully and more rapidly in the border zone. The economic considerations put forward since the creation of the Central Commission for Combating Contraband were fundamental in this respect. The goal was to fight against illegal commercial activity and to undermine the basis of foreign economic influence in the border areas. In early 1923, this commission had strengthened its presence at the local level, setting up commissions for each district together with operational customs posts located deeper in the interior, in advance of the border zone. ${ }^{84}$ In Ukraine, the trade in gemstones and precious metals was forbidden inside a border zone of 15 kilometers from February 1923. ${ }^{85}$ In March of that year, transactions in gold and the export of raw materials were forbidden in Belorussia within a border zone of 21 kilometers. ${ }^{86}$ With the support of the customs services, the practice of keeping files on persistently offending smugglers was initiated on a large scale. This undertaking was also extended to certain business communities that were considered suspicious. Since 1922, representatives of the GPU had been asking for lists of unreliable elements in the transport sector to be drawn up. With the implementation of the border zone came the first layoffs and transfers of Polish railway workers. The customs services were also purged, as their staff, often in the same posts since before the revolution, had numerous acquaintances on the other side of the border. On the western border, woodcutters, up to 50 percent of whom could be-to use the term employed in a Chekist report from Olevsk in the Volhynia province_- "pardoned bandits," were considered "informers for the Polish intelligence services and instigators of counterrevolutionary agitation," as were workers in sugar refineries. ${ }^{87}$ The first purges in the border zone thus affected certain professional sectors that were considered sensitive and took the form of relocations to the interior of the country, with the aim of removing individuals suspected of spying or smuggling from the border area. Besides particular social categories, they also targeted certain nationalities, particularly nationals of hostile neighboring states with family on the other side of the boundary. ${ }^{88}$ During the early 1920 s, then, the threat of danger along

84. For instance, a commission for combating contraband was created on the Karelian Isthmus on January 5, 1923, and customs barriers were set up 7 kilometers from the border.

85. GARF, 130/6/642, p. 5, cited in Chandler, Institutions of Isolation, 144.

86. NARB, 6/1/175, p. 16.

87. NARB, 6/1/224, p. 124. russians professing the Catholic faith, considered by the Chekists to be Poles in disguise. 
the border was merely a question of geography. A suspicious individual had only to be relocated to the interior to become a harmless citizen. Ten years later, that would no longer suffice, and connections with the outside world would become a stigma that could never be escaped. The registration of all the inhabitants of the border zone, stipulated in the decrees, contained the seeds of the close monitoring imposed on citizens of the newly constituted USSR as well as foreigners residing in the border area.

The Soviet state was not alone in developing a strict system of control over inhabitants in border zones. All the neighboring states also gave their border police wider powers. This was particularly apparent after 1924, a time when, as the formation of the USSR was being finalized, issues of sovereignty hardened along the borders of eastern Europe. Other countries, however, were slower than the USSR in taking concrete measures. In Poland, the first decisions to relocate Ukrainians and Belorussians belonging to the rural elite to the interior of the country were not made until $1928 .{ }^{89}$ The objective was not so much control of the interface as integration into the territory. While the Poles also sought to undermine Soviet espionage bases in the border zone with these measures, it was above all a question of putting an end to the anti-Polish terrorist activities of Ukrainian organizations that endangered the country's territorial integrity.

In all these countries, the assertion of sovereignty over their borderlands was achieved by implementing a specific policy in the border regions. Its objectives, ultimately shaped by the question of loyalty, were threefold: the civic integration of borderland populations often belonging to national minorities; a display of newly acquired state identity for the benefit of adjacent neighbors; and the physical and symbolic occupation of the area. The government in Bucharest developed a policy of Romanianization in Bessarabia and Bucovina. ${ }^{90}$ The Czech government implemented a policy prioritizing investments in Sub-Carpathian Ruthenia as a gesture toward Hungary. In Helsinki in 1923, the Finnish Council of State launched a policy designed to redress economic imbalances in order to "nationalize" the area along its eastern periphery. ${ }^{91}$ In the USSR, the creation of a commission to improve the border zones in 1925 was likewise aimed at resolving economic and cultural imbalances in order to demarginalize these areas. ${ }^{92}$ However, the specificity of the Soviet construction of space in both political and policing terms no doubt lies in the fact that control of the interface appears to have taken precedence over territorial homogenization. The territorialization and institutionalization of an internal

89. Rossiiskii Gosudarstvennyi Voennyi Arkhiv/Osobyi Arkhiv, Korpus Ochrony Pogranicza collection, 356/2/4.

90. This policy, which sought to impose the teaching of Romanian in schools and universities, was a failure in the multiethnic towns of Bessarabia and Bucovina: see Irina Livezeanu, Cultural Politics in Greater Romania: Regionalism, Nation Building, and Ethnic Struggle, 1918-1930 (Ithaca: Cornell University Press, 1995).

91. Anssi Paasi, Territories, Boundaries and Consciousness: The Changing Geographies of the Finnish-Russian Border (Chichester: John Wiley \& Sons, 1996), 170-80.

92. RGASPI, 17/3/511, pp. 518 and 519. 
border zone and the obsession with monitoring circulation, which were unparalleled anywhere else, inscribed the effects of the border within a specific geography. The rights and duties, the constraints and privileges associated with life in the border zone resulted in a differentiation from the rest of the territory. With "passportization" in the 1930 s, this spatialization of ultracontrolled yet privileged special zones was to become a mode of refashioning the territory that was implemented throughout the country as a whole. ${ }^{93}$

From pioneer front to controlled zone, the Bolsheviks' border was particularly thick. The territorial representations and practices of revolutionary Russia ultimately proved to be the antithesis of their counterparts in the newly-formed states on its western borders. Far from leading to a single, indivisible republic, the Soviet federal project, coupled with the practice of national autonomy, resulted in a multiplication of borders following a revolutionary, expansionist logic. Moreover, the focus of politicians and police services on this interface led to the rapid institutionalization of a specific zone that was lastingly dissociated from the rest of the territory. Yet this construction, although rooted in an essentially unilateral project, was not undertaken independently of the neighboring states. As the study of border diplomacy in these formative and transitional years reveals, the Bolsheviks were capable of cooperating with adjacent states and even proved to be particularly innovative in this respect. To borrow the insightful theme of Robert Frost's "Mending Wall," the communal construction of a boundary was a means of living together or, in Soviet terminology, coexisting peacefully. ${ }^{94}$ These interactions resulted in transfers and mimetism when it came to administrative norms and control mechanisms, as illustrated by the examples of buffer zones and practices designed to cleanse and stabilize the borderlands. However, the potentially normalizing factor of day-today negotiations over sovereignty in no way changed the political representation of a radical otherness and an interface between two antagonistic systems of thought. As a result, the progressive closure of this border by the Soviets, which could be considered complete in the latter half of the 1930s, shows the boomerang effect of the territorial question, prompted by the regime's needs for protection. Territorial exclusivity was thus equated with political domination and control of the population from an early date.

Sabine Dullin

(Université Charles de Gaulle Lille 3, IRHIS)

Sciences Po Paris, CHSP

93. Nathalie Moine, "Le système des passeports à l'époque stalinienne. De la purge des grandes villes au morcellement du territoire, 1932-1953," Revue d'histoire moderne et contemporaine 50, no. 1 (2003): 145-69.

94. Robert Frost, North of Boston (New York: Henry Holt and Co., 1915), 11-13. 